Innowacje w Pielęgniarstwie i Naukach o Zdrowiu

$2(1) / 2016$

ISSN: 2451-1846

DOI: http://dx.doi.org/10.21784/IwP.2016.010

Magdalena Gościcka ${ }^{1}$

${ }^{1}$ Wojewódzki Szpital Zespolony w Płocku, Oddział Chorób Płuc i Gruźlicy

\title{
Ocena akceptacji choroby przewlekłej na przykładzie pacjentów z przewlekłą obtura- cyjną chorobą płuc
}

\section{Assessment of chronic disease acceptance based on the example of patients with chronic obstructive pulmonary disease}

\section{Streszczenie}

Wstęp. Przewlekła obturacyjna choroba płuc to jedna z najczęściej występujących chorób na świecie. Stanowi ona jeden z najważniejszych problemów społecznych powodując wysoką śmiertelność. Zmiany powstające w płucach charakteryzują się niecałkowicie odwracalnym ograniczeniem przepływu powietrza przez drogi oddechowe. Leczenie chorych z przewlekłą obturacyjną chorobą płuc polega na zapobieganiu postępowi choroby oraz ograniczeniu czynników wywołujących chorobę i jej zaostrzenia. Na jakość życia chorych z przewlekłą obturacyjną chorobą płuc ma znaczący wpływ rehabilitacja oddechowa, która jest jednym z elementów terapii. Rehabilitacja obejmuje całość działań mających na celu poprawę stanu fizycznego, psychicznego i społecznego pacjenta. 
Cel. Celem badań jest ocena poziomu akceptacji choroby przewlekłej na przykładzie pacjentów z przewlekłą obturacyjną chorobą płuc oraz zbadanie wpływu czynników kształtujących określony poziom akceptacji choroby.

Materiał i metody. Badania przeprowadzono w Wojewódzkim Szpitalu Zespolonym w Płocku. Grupę badaną stanowiło 100 pacjentów w Oddziale Chorób Płuc i Gruźlicy. Badania przeprowadzono metodą szacowania i metodą sondażu diagnostycznego. Jako narzędzie badawcze posłużyła Skala Akceptacji Choroby oraz kwestionariusz ankiety.

Wyniki. Wykonane badania dowiodły, że pacjenci akceptują chorobę na poziomie średnim. Na ocenę akceptacji choroby wpływają czynniki zdrowotne, psychiczne i społeczne.

Wnioski. 1. Poziom akceptacji przewlekłej obturacyjnej choroby płuc nie zależy istotnie od płci, wieku, wykształcenia, stanu cywilnego oraz sposobu zamieszkania. 2. Poziom akceptacji przewlekłej obturacyjnej choroby płuc zależy istotnie od miejsca zamieszkania. Pacjenci zamieszkujący w mieście przejawiają wyższy poziom akceptacji choroby w porównaniu z pacjentami mieszkającymi na wsi. 3. Poziom akceptacji przewlekłej obturacyjnej choroby płuc zależy istotnie od chorób współistniejących. Pacjenci mający choroby współistniejące prezentują niższy poziom akceptacji choroby w odniesieniu do pacjentów pozbawionych innych chorób.

\begin{abstract}
Introduction. Chronic obstructive pulmonary disease is one of the most common diseases in the world. It is one of the most important social problems causing high mortality. The changes occurring in the lungs are characterized by not fully reversible airflow limitation through air passages. Treatment of patients with chronic obstructive pulmonary disease consists in the prevention of the disease progression and reduction of the factors that cause the disease and its exacerbation. The quality of life in patients with chronic obstructive pulmonary disease is significantly affected by pulmonary rehabilitation, which is part of the therapy. Rehabilitation includes all measures aimed at improving the physical, mental and social health of the patient.

Aim. The aim of the study is to assess the level of acceptance of chronic disease based on the example of patients with chronic obstructive pulmonary disease and to study the impact of factors forming a certain level of the disease acceptance.
\end{abstract}


Material and Methods. The study was conducted at the Provincial Hospital in Plock. The study group consisted of 100 patients in the Department of Pulmonary Diseases and Tuberculosis. The research was carried out by means of an estimating method and a diagnostic survey. The Disease Acceptance Scale as well as the survey questionnaire were used as the research tools.

Results. The studies have shown that patients accept the disease at the secondary level. The disease acceptance assessment are affected by health, psychological and social factors.

Conclusions. 1 . The acceptance level of chronic obstructive pulmonary disease does not depend significantly on gender, age, education, marital status and the way of residing. 2 . The acceptance of chronic obstructive pulmonary disease depends significantly on the place of one's residence. Patients residing in the city exhibit a higher level of acceptance of the disease compared with those living in the countryside. 3 . The acceptance of chronic obstructive pulmonary disease depends significantly on comorbidities. Patients with concomitant diseases present a lower level of acceptance of the disease than patients without other diseases.

Słowa kluczowe: przewlekła obturacyjna choroba płuc, akceptacja choroby, pacjent

Keywords: chronic obstructive pulmonary disease, acceptance of the disease, the patient

\section{Wstęp}

Przewlekła obturacyjna choroba płuc (POChP) jest znaczącym problemem medycznym oraz społecznym. Według informacji Światowej Organizacji Zdrowia na umiarkowaną lub ciężką postać cierpi około 80 milionów ludzi na świecie. W Polsce na POChP choruje ponad $20 \%$ populacji powyżej 40 roku życia, a po 70 roku życia jest to nawet 50\%. Choroba ta oceniania jest obecnie jaka czwarta co do częstości przyczyn zgonów na świecie. Pojawienie się tej choroby może ale nie musi być ściśle związane z nałogiem palenia papierosów. Szacuje się, że około $30 \%$ osób chorych to osoby, które nigdy nie paliły 
albo były, bądź są palaczami biernymi. Przewlekła obturacyjna choroba płuc występuje częściej u mężczyzn niż u kobiet, stosunek płci wynosi 2:1. Choroba ta jest jedną z najczęściej występujących chorób przewlekłych w Polsce [1].

Przewlekła obturacyjna choroba płuc charakteryzuje się przewlekłym ograniczeniem przepływu powietrza przez drogi oddechowe. W płucach zauważalne są liczne zmiany patologiczne oraz zmiany pozapłucne. Zmiany powstające w płucach charakteryzują się niecałkowicie odwracalnym ograniczeniem przepływu powietrza przez drogi oddechowe. Ograniczenie to wynika z reakcji organizmu na szkodliwe gazy oraz pyły. Szczególnie dla przewlekłej obturacyjnej choroby płuc ograniczenie przepływu powietrza przez drogi oddechowe jest wywołane jednocześnie przez chorobę małych dróg oddechowych (obturacyjne zapalenie oskrzelików) jak i zniszczenie miąższu płuc (rozedma). Choroba ta jest chorobą ogólnoustrojową, poddająca się prewencji i leczeniu co wiąże się z prawidłowym schematem postępowania profilaktycznego, diagnostycznego i terapeutycznego $[2,3]$.

Typowymi objawami dla POChP są duszność wysiłkowa oraz kaszel z odkrztuszaniem szczególnie w godzinach porannych. Inne objawy, które mogą wskazywać na POChP to ból w klatce piersiowej oraz krwioplucie. W przebiegu przewlekłej obturacyjnej choroby płuc duszność jest jednak najważniejszym i najbardziej uciążliwym problemem. Duszność zwiększa się, początkowo występuje podczas wysiłku a z upływem czasu dochodzi do duszności spoczynkowej. Duszność tak jak kaszel nasila się w godzinach porannych. Duszność spoczynkowa informuje o ciężkiej postaci choroby. U chorych z przewlekłą obturacyjną chorobą płuc nietolerancja wysiłku fizycznego stanowi jeden $\mathrm{z}$ głównych czynników uniemożliwiających udział w czynnościach życia codziennego lub. Czynności te ograniczane są przez duszność i zmęczenie wynikające $\mathrm{z}$ upośledzonej wentylacji płuc [4]. 
Rozpoznanie choroby ustala się na podstawie wywiadu, badania przedmiotowego oraz badań spirometrycznych. Duże znaczenie w postawieniu diagnozy mają również badania radiologiczne klatki piersiowej, elektrokardiograficzne, echokardiograficzne oraz gazometryczne krwi [5].

Leczenie chorych z przewlekłą obturacyjną chorobą płuc polega na zapobieganiu postępowi choroby, ograniczeniu czynników wywołujących chorobę i jej zaostrzenia. Obecnie stosowane jest leczenie farmakologiczne, chirurgiczne, leczenie tlenem, rehabilitacja oddechowa i fizykoterapia. W leczeniu przewlekłej obturacyjnej choroby płuc nie bez znaczenia są szczepienia przeciwko grypie. Stosowanie tego typu szczepionki zmniejsza częstość zaostrzeń chorobowych oraz śmiertelność [6].

Leczenie farmakologiczne chorych z przewlekłą obturacyjną chorobą płuc ma na celu poprawę wentylacji płuc, złagodzenie objawów choroby, zminimalizowanie ilości i ciężkości zaostrzeń. Mówiąc o leczeniu farmakologicznym POChP mówimy o zminimalizowaniu zmian patofizjologicznych takich jak: zwiększone wytwarzanie śluzu, skurcz mięśni gładkich oskrzeli, obrzęk błony śluzowej oskrzeli, zapalenie dróg oddechowych. Leki zmniejszające objawy oraz częstość zaostrzeń to: kortykosteroidy wziewne, leki rozszerzające oskrzela, antyoksydanty i mukolityki [2].

W terapii chorego z POChP istotne znaczenie ma rehabilitacja, która korzystnie wpływa na jakość życia chorych. Rehabilitacja swoim spektrum obejmuje całość zdarzeń mających na celu poprawę wydolności wysiłkowej, poprawę sprawności ogólnej oraz zmniejszenie częstości hospitalizacji. U chorych z POChP rehabilitacja nie jest w stanie zatrzymać procesu patofizjologicznego ale uczy chorego funkcjonowania z tym upośledzeniem. Poprawa jakości życia po cyklu zabiegów rehabilitacyjnych utrzymuje się przez dłuższy czas po ich zakończeniu. Pomiar jakości życia pacjenta z POChP to główny element oceny efektów rehabilitacji. Ocena ta powinna być rutynowym parametrem kompleksowej oceny stanu chorego $[7,8]$. 
Jakość życia chorych z POChP znacznie obniża się. U chorych na ciężką postać POChP obserwuje się spadek aktywności psychicznej i fizycznej, obniżenie jakości snu, obniżenie reakcji emocjonalnych, pogorszenie samopoczucia oraz izolację społeczną. Chorzy stają się zależni od drugiej osoby. Obserwujemy również zmiany w hierarchii wartości, znacznie większego znaczenia nabierają wartości niematerialne, takie jak religia czy relacje z rodziną [9].

Celem badań była ocena poziomu akceptacji choroby przewlekłej na przykładzie pacjentów z przewlekłą obturacyjną chorobą płuc oraz zbadanie wpływu czynników kształtujących określony poziom akceptacji choroby.

\section{Materiał i metody}

Badania przeprowadzono w Wojewódzkim Szpitalu Zespolonym w Płocku w Oddziale Chorób Płuc i Gruźlicy w okresie od 10 sierpnia 2015 roku do 30 stycznia 2016 roku. Na wykonanie badań uzyskano zgodę Komisji Bioetycznej UMK w Toruniu, Collegium Medicum w Bydgoszczy - KB 405/2015. Grupę badaną stanowiło 100 pacjentów, zarówno kobiety jak i mężczyźni w wieku od 46 lat do 76 lat. Badania przeprowadzono metodą szacowania i metodą sondażu diagnostycznego. Jako narzędzie badawcze posłużyła standaryzowana Skala Akceptacji Choroby (Acceptance of IllnessScale - AIS) oraz kwestionariusz ankiety dotyczący danych socjodemograficznych. Skala AIS została wykorzystana za zgodą Pracowni Testów Psychologicznych Polskiego Towarzystwa Psychologicznego w Warszawie. Obliczenia statystyczne wyników badań wykonano za pomocą pakietu SPSS Statistica 21,0. Do zbadania zależności pomiędzy analizowanymi zmiennymi użyto testu jednorodności chi kwadrat. Wartość prawdopodobieństwa $\mathrm{p}<0,05$ uznano za statystycznie istotną.

\section{Wyniki}

Zastosowana Skala Akceptacji Choroby pozwoliła na ocenę stopnia akceptacji choroby wśród chorych z przewlekłą obturacyjną cho- 
robą płuc. Skala ta zawierała 8 stwierdzeń opisujących negatywne konsekwencje złego stanu zdrowia. Następstwa te sprowadzają się do uznania ograniczeń narzuconych przez sytuację zdrowotną, braku samowystarczalności, poczucia zależności od innych osób oraz obniżonego poczucia własnej wartości. W każdym stwierdzeniu badany pacjent określał za pomocą pięciostopniowej skali swój aktualny stan, wskazując odpowiednią wartość punktową. Akceptacja choroby jest sumą wszystkich punktów i mieści się w obszarze od 8 do 40 punktów. Im wyższy wynik tym większa jest akceptacja choroby, co oznacza lepsze przystosowanie się do ograniczeń narzuconych przez sytuację zdrowotną i mniejsze poczucie dyskomfortu psychicznego związanego z obecną chorobą. Niski wynik oznacza brak akceptacji i przystosowania się do choroby oraz brak poczucia dyskomfortu psychicznego, co może przejawiać się negatywnymi emocjami związanymi $\mathrm{z}$ chorobą [10].

W tabeli 1 przedstawiono uzyskane wyniki z badań własnych dotyczące poziomu akceptacji przewlekłej obturacyjnej choroby płuc wśród osób badanych.

Tabela 1. Poziom akceptacji choroby według ogólnej klasyfikacji Skali AIS.

\begin{tabular}{|l|c|c|c|}
\hline \multicolumn{1}{|c|}{ Poziom akceptacji } & punkty & liczebność & $\%$ \\
\hline Poziom niski & $8-19$ & 25 & 25 \\
\hline Poziom średni & $20-35$ & 65 & 65 \\
\hline Poziom wysoki & $36-40$ & 10 & 10 \\
\hline
\end{tabular}

Źródło: opracowanie własne.

Jak wynika z przedstawionych wyników dominującą grupę stanowią chorzy wykazujący średni poziom akceptacji choroby (65\%). Niski poziom akceptacji stwierdzono u 25\% respondentów. Wysoki poziom akceptacji prezentuje $10 \%$ osób badanych. 
Tabela 2. Poziom akceptacji choroby według szczegółowych kategorii Skali AIS.

\begin{tabular}{|l|c|c|}
\hline \multicolumn{1}{|c|}{ Kategorie Skali AIS } & $\begin{array}{c}\text { Średnia } \\
\text { ocen (x) }\end{array}$ & $\begin{array}{c}\text { Odchy- } \\
\text { lenie } \\
\text { standar- } \\
\text { dowe }\end{array}$ \\
\hline $\begin{array}{l}\text { Mój stan zdrowia sprawia, że nie czuję się } \\
\text { pełnowartościowym człowiekiem. }\end{array}$ & 3,44 & 1,32 \\
\hline $\begin{array}{l}\text { Choroba sprawia, że jestem ciężarem dla } \\
\text { swojej rodziny i przyjaciół. }\end{array}$ & 3,42 & 1,34 \\
\hline $\begin{array}{l}\text { Choroba sprawia, że czasem czuję się niepo- } \\
\text { trzebny. }\end{array}$ & 3,34 & 1,30 \\
\hline $\begin{array}{l}\text { Myślę, że ludzie przebywający ze mną są } \\
\text { często zakłopotani z powodu mojej choroby. }\end{array}$ & 3,33 & 1,32 \\
\hline $\begin{array}{l}\text { Problemy ze zdrowiem sprawiają, że jestem } \\
\text { bardziej zależny od innych niż tego chcę. }\end{array}$ & 3,03 & 1,39 \\
\hline $\begin{array}{l}\text { Z powodu swojego stanu zdrowie nie jestem } \\
\text { w stanie robić tego, co najbardziej lubię. }\end{array}$ & 3,02 & 1,27 \\
\hline $\begin{array}{l}\text { Mam kłopoty z przystosowaniem się do } \\
\text { ograniczeń narzuconych przez chorobę. }\end{array}$ & 2,85 & 1,31 \\
\hline $\begin{array}{l}\text { Nigdy nie będę samowystarczalnym w takim } \\
\text { stopniu, w jakim chciałbym być. }\end{array}$ & 2,83 & 1,43 \\
\hline
\end{tabular}

Źródło: opracowanie własne

W powyższej tabeli 2 przedstawiono wartości średnie dla poszczególnych stwierdzeń skali AIS, które zawierają się od $\mathrm{x}=2,83$ do $\mathrm{x}=3,44$. Najniższą średnią, a tym samym najniższy poziom akceptacji 
choroby zanotowano dla stwierdzeń: „nigdy nie będę samowystarczalnym $\mathrm{w}$ takim stopniu, $\mathrm{w}$ jakim chciałbym być" $(\mathrm{x}=2,83)$ oraz „mam kłopoty z przystosowaniem się do ograniczeń narzuconych przez chorobę $(\mathrm{x}=2,85)$. Najwyższą średnią wartość, a tym samym najwyższy średni stopień akceptacji choroby zanotowano dla stwierdzeń: „mój stan zdrowia sprawia że nie czuję się pełnowartościowym człowiekiem” $(x=3,44)$ oraz „choroba sprawia, że jestem ciężarem dla swojej rodziny i przyjaciół" $(=3,42)$.

Analiza statystyczna nie wykazała istotnej zależności pomiędzy płcią ankietowanych, a ich poziomem akceptacji choroby $(\mathrm{p}=0,473)$. Ponad 61\% kobiet oraz ponad 68\% mężczyzn wykazuje średni poziom akceptacji choroby. Niski poziom akceptacji choroby wykazano jednocześnie u 25\% kobiet i 25\% mężczyzn. Wysoki poziom akceptacji choroby przejawia ponad $13 \%$ kobiet i ponad 6\% mężczyzn.

W analizie statystycznej nie wykazano istotnej zależności pomiędzy wiekiem ankietowanych, a ich poziomem akceptacji choroby $(\mathrm{p}=0,078)$. Ponad $67 \%$ osób w wieku 46-60 lat oraz ponad $61 \%$ osób w wieku 61-76 lat wykazuje średni poziom akceptacji choroby. Niski poziom akceptacji występuje u ponad $17 \%$ osób w wieku 46-60 lat oraz ponad 34\% u osób w wieku 61-76 lat. Natomiast wysoki poziom akceptacji choroby stwierdzono u ponad $14 \% \mathrm{w}$ wieku $46-60$ lat i ponad 4\% u osób w wieku 61-76 lat.

Analizując wyniki badań nie stwierdzono istotnej statystycznie zależności pomiędzy wykształceniem ankietowanych, a ich poziomem akceptacji choroby $(\mathrm{p}=0,16)$. Ponad $56 \%$ osób z wykształceniem wyższym lub średnim oraz ponad $73 \%$ osób $\mathrm{z}$ wykształceniem podstawowym lub zawodowym wykazuje średni poziom akceptacji choroby. Niski poziom akceptacji choroby wykazano u ponad 29\% osób z wykształceniem wyższym lub średnim i u ponad $21 \%$ osób z wykształceniem podstawowym lub zawodowym. Wysoki poziom akceptacji choroby występuje u ponad $14 \%$ posiadających wykształcenie wyższe lub średnie i u ponad 5\% osób z wykształceniem podstawowym lub zawodowym. 
Analiza statystyczna nie wykazała istotnej zależności pomiędzy stanem cywilnym ankietowanych a ich poziomem akceptacji choroby $(\mathrm{p}=0,23)$. Ponad $71 \%$ osób będących w związku oraz ponad $55 \%$ osób w stanie wolnym wykazuje średni poziom akceptacji choroby. Niski poziom akceptacji choroby zadeklarowało 20\% osób będących w związku i ponad 32\% osób stanu wolnego. Wysoką akceptację choroby posiada ponad $8 \%$ pozostających w związku i ponad $12 \%$ stanu wolnego.

Analiza statystyczna wykazała istotną zależność pomiędzy miejscem zamieszkania ankietowanych, a ich poziomem akceptacji choroby $(p=0,011)$. Ponad $69 \%$ osób mieszkających $w$ mieście wykazuje średni poziom akceptacji choroby, natomiast niski poziom uzyskało ponad $16 \%$, a wysoki ponad $14 \%$ badanych. Wśród ponad $57 \%$ osób mieszkających na wsi występuje średni poziom akceptacji choroby, natomiast aż ponad $39 \%$ określa poziom jako niski, a tylko ponad $2 \%$ poziom wysoki.

Według analizy statystycznej nie występuje istotna zależności pomiędzy sposobem zamieszkania ankietowanych, a ich poziomem akceptacji choroby $(\mathrm{p}=0,849)$. Ponad $66 \%$ osób mieszkających z opiekunem lub rodziną oraz ponad $60 \%$ osób mieszkających samotnie wykazuje średni poziom akceptacji choroby. Ponad 23\% badanych mieszkających z rodziną i ponad 28\% mieszkających samotnie prezentuje niski poziom akceptacji choroby. Jako wysoką akceptację choroby określa ponad $9 \%$ osób, którzy mieszkają z rodziną oraz ponad 10\% osób mieszkających samotnie.

Analiza statystyczna wykazała istotną zależność pomiędzy występowaniem chorób współistniejących $\mathrm{u}$ ankietowanych, a ich poziomem akceptacji choroby $(\mathrm{p}=0,011)$. U osób, u których występują choroby współistniejące niski poziom akceptacji choroby określa aż ponad $28 \%$ badanych, średni poziom występuje u ponad $61 \%$, a wysoki u ponad 9\%. Natomiast wśród osób, u których jest brak chorób współistniejących niski poziom akceptacji choroby prezentuje ponad 
20\%, średni poziom określa ponad 78 \% osób, a wysoki poziom określiło ponad $10 \%$ badanych.

\section{Dyskusja}

Wykonanie badań własnych i ich analiza pozwoliły ocenić poziom akceptacji choroby przewlekłej na przykładzie pacjentów z przewlekłą obturacyjną chorobą płuc oraz zbadać wpływ czynników kształtujących określony poziom akceptacji choroby. Ankietowani pacjenci w zdecydowanej większości prezentują poziom akceptacji choroby jako średni - 65\%, niski poziom występuje u $25 \%$ osób, a u $10 \%$ jest to poziom wysoki. Najniższy poziom akceptacji choroby zaobserwowano dla stwierdzeń: „nigdy nie będę samowystarczalnym w takim stopniu, w jakim chciałbym być” oraz „mam kłopoty z przystosowaniem się do ograniczeń narzuconych przez chorobę. Najwyższy stopień akceptacji choroby zanotowano dla stwierdzeń: „mój stan zdrowia sprawia że nie czuję się pełnowartościowym człowiekiem" oraz „choroba sprawia, że jestem ciężarem dla swojej rodziny i przyjaciół”.

Analiza wyników badań własnych dowiodła, że występuje częściowa zależność poziomu akceptacji przewlekłej obturacyjnej choroby płuc w odniesieniu do czynników socjodemograficznych badanej grupy pacjentów i współistniejących chorób.

Kobiety wykazały wyższy poziom akceptacji choroby jaką stanowi POChP niż mężczyźni. Podobne wyniki otrzymała A. Majda i H. Józefowska, gdzie kobiety wykazały wyższy poziom akceptacji choroby niż mężczyźni. Badania zostały przeprowadzone na podstawie Skali Akceptacji Choroby [11]. Podobne wyniki otrzymano również w badaniach K. Bąk-Drabik i D. Ziora, gdzie w badaniach udział wzięło 57 mężczyzn i 39 kobiet, to właśnie kobiety wykazały wyższy poziom akceptacji choroby jaką stanowi przewlekła obturacyjna choroba płuc [9].

Analizując poziom akceptacji choroby pod względem wieku badanych wykazano iż, respondenci w młodszej kategorii wiekowej prezentują wyższy poziom akceptacji choroby przewlekłej. Odmienne 
wyniki uzyskano w badaniach, które przeprowadziły D. Olek, I. Uchmanowicz, A. Chudziak, B. Jankowska-Polańska, gdzie stwierdzono, że osoby w starszej kategorii wiekowej wykazują znacznie częściej wyższy poziom akceptacji choroby, niż osoby w młodszej kategorii wiekowej [12].

Analiza poziomu akceptacji choroby pod względem wykształcenia badanych wykazała, iż respondenci posiadający wykształcenie wyższe i średnie odczuwają wyższy poziom akceptacji choroby niż osoby $\mathrm{z}$ wykształceniem podstawowym i zawodowym. W badaniach opierających się na Skali Akceptacji Choroby, które przeprowadziły K. BąkDrabik i D. Ziora wykazano także, że osoby z wyższym oraz średnim wykształceniem prezentują wyższy poziom akceptacji choroby przewlekłej jaką stanowi POChP [9].

$\mathrm{W}$ analizie poziomu akceptacji choroby pod względem stanu cywilnego badanych, wykazano, iż pacjenci przebywający w związku małżeńskim posiadają wyższy poziom akceptacji choroby przewlekłej jaką stanowi POChP. Przypuszczalnie wynika to z uzyskanego wsparcia psychicznego oraz organizacji i pomocy w czynnościach codziennych. Zbliżone wyniki uzyskano $\mathrm{w}$ badaniach, które przeprowadziły B. Kowalczyk-Soroka, H. Marmurowska -Michałowska i M. Knap i wykazały, że stan cywilny badanych osób wpływa na poziom akceptacji przewlekłej obturacyjnej choroby płuc [13].

Analizując poziom akceptacji choroby pod względem miejsca zamieszkania zaobserwowano, że chorzy mieszkający w mieście wykazali istotnie wyższy poziom akceptacji choroby jaką stanowi POChP w stosunku do mieszkańców wsi. Przypuszczalnie może to wynikać z szybszego dostępu do specjalistycznej opieki medycznej w szpitalach ale również uwarunkowane może to być także pozycją jaką chory zajmuje w określonym środowisku. Podobne wyniki uzyskano w badaniach A. Majdy i H. Józefowskiej, gdzie większość badanych mieszkających w mieście osiągnęła wyższy poziom akceptacji choroby przewlekłej jaką stanowi POChP [11]. 
W toku analizy poziomu akceptacji choroby pod względem sposobu zamieszkania wykazano, iż pacjenci zamieszkujący $\mathrm{w}$ rodziną ewentualnie opiekunem wykazują wyższy poziom akceptacji choroby przewlekłej jaką stanowi POChP. Przypuszczalnie wynika to z faktu otrzymywanej pomocy i wsparcia od osób trzecich w zakresie czynności dnia codziennego. Podobne wyniki w tym zakresie uzyskała M. Iwanicka - Michałowicz i I. Grzelewska-Rzymowska w badaniach przeprowadzonych na grupie 200 osób [14].

Na podstawie analizy poziomu akceptacji choroby pod względem współwystępowania innych chorób poza POChP wykazano, iż choroby współistniejące występują aż u $81 \%$ badanych. Występowanie tych chorób wpływa negatywnie na poziom akceptacji choroby zasadniczej jaką stanowi POChP. Choroby te obniżają samoocenę, sprawność fizyczną oraz psychiczną. Podobne wyniki zaprezentowała K. Walden Gałuszko, J. Milanowski, J. Zieliński, którzy stwierdzają, że respondenci bez chorób współistniejących wykazują zdecydowanie wyższy poziom akceptacji choroby niż pacjenci obciążeni innymi chorobami [15].

Pomimo poważnych i często zaawansowanych objawów przewlekłej obturacyjnej choroby płuc pacjenci akceptują fakt choroby w stopniu średnim. Ze względu na problemy natury fizycznej, psychicznej i społecznej jakie spotykają chorzy z POChP w życiu codziennym należy poświęcić im dużo zrozumienia, cierpliwości i troski w sprawowaniu opieki i dążeniu do jak najlepszego ich funkcjonowaniu.

\section{Wnioski}

1. Chorzy z przewlekłą obturacyjną chorobą płuc prezentują średni poziom akceptacji choroby.

2. Poziom akceptacji choroby wśród chorych z przewlekłą obturacyjną chorobą płuc nie zależy istotnie od płci, wieku, wykształcenia i sposobu zamieszkania osób badanych. 
3. Poziom akceptacji choroby wśród chorych z przewlekłą obturacyjną chorobą płuc zależy istotnie od miejsca zamieszkania. Chorzy mieszkający w mieście przejawiają wyższy poziom akceptacji choroby w porównaniu z chorymi mieszkającymi na wsi.

4. Poziom akceptacji choroby wśród chorych z przewlekłą obturacyjną chorobą płuc zależy istotnie od współistniejących chorób. Chorzy, u których występują dodatkowe choroby prezentują niższy poziom akceptacji choroby w odniesieniu do grupy chorych bez współistniejących chorób.

\section{Zalecenia dla praktyki pielęgniarskiej}

Poziom akceptacji choroby przewlekłej przez chorego ma duże znaczenie $\mathrm{w}$ świadczeniu opieki profesjonalnej jak i pozyskaniu pacjenta do działań w zakresie samoopieki i samokontroli w środowisku domowym. Im wyższy poziom akceptacji choroby tym bardziej konstruktywna i zaangażowana postawa pacjenta w walce $\mathrm{z}$ chorobą przyczyniająca się do zwiększenia wymiarów jakości życia. W dążeniu do uzyskania wysokiego poziomu akceptacji choroby należy pozyskać, zaangażować i koordynować kompleksowe działania zespołu terapeutycznego, środowiska rodzinnego i grupy zawodowej pacjenta.

\section{Bibliografia / Bibliography:}

1. Jasik A., Marcinowska - Suchowierska E. Przewlekła obturacyjna choroba płuc. Postępy Nauk Medycznych. 2009;(22)5:340-344.

2. Chyczewska E., Górecka D. Światowa strategia rozpoznawania, leczenia i prewencji przewlekłej obturacyjnej choroby płuc. Medycyna Praktyczna. 2008;2:12-89.

3. Matynia A., Porzych K., Porzych M., Kędziora-Kornatowska K., Motyl J., Polak A. Zachowania zdrowotne osób w podeszłym wieku. W: Krajewska-Kułak E., Szczepański M., Łukaszuk C., Lewko J. (red.), Problemy te- 
rapeutyczno-pielęgnacyjne od poczęcia do starości. Tom I. Wydawnictwo Akademia Medyczna w Białymstoku. Białystok 2007:376-384.

4. Zieliński J. Przewlekła obturacyjna choroba płuc. Wydawnictwo Medyczne Górnicki. Wrocław 2006:21-30,60-70.

5. Kozielski J. i wsp. Zalecenia Polskiego Towarzystwa Ftizjopneumonologicznego rozpoznawania i leczenia POChP. Medycyna po Dyplomie. 2003;(wyd. spec.):9-10

6. Pierzchała W., Barczyk A., Górecka D., Śliwiński P., Zieliński J. Zalecenia Polskiego Towarzystwa Chorób Płuc. Rozpoznawanie i leczenie POChP. Pneumonologia i Alergologia Polska. 2010;(78)5:17-35.

7. Kasiborska-Kuźniar K., Jankowska R., Kuźniar T. Wpływ rehabilitacji oddechowej na jakość życia chorych na przewlekłą obturacyjną chorobę płuc. Wiadomości Lekarskie. 2007;60(3-4):158-161.

8. Kozielski J. Czy chory na POChP odnosi korzyści z rehabilitacji skojarzonej $\mathrm{z}$ leczeniem farmakologicznym? Pneumonologia i Alergologia Polska. 2012;(80)4:463-466.

9. Bąk-Drabik K., Ziora D. Jakość życia w przewlekłej obturacyjnej chorobie płuc. Pneumonologia i Alergologia Polska. 2004;(72)supl.1:128-133.

10. Felton B,J., Revenson T.A., Hinrichsen G.A. AIS. Adaptacja: Z. Juczyński. Pracownia Testów Psychologicznych Polskiego Towarzystwa Psychologicznego. Warszawa 2012.

11. Majda A., Józefowska H. Zasoby osobiste pacjentów z przewlekłą obturacyjną chorobą płuc. Problemy Pielęgniarstwa. 2009;(17)4:283-293.

12. Olek D., Uchmanowicz I., Chudiak A., Jankowska-Polańska B. Wpływ akceptacji choroby na jakość życia chorych w przewlekłej obturacyjnej chorobie płuc. Problemy pielęgniarstwa. 2014;(22)4:471-476. 
13. Kowalczyk-Soroka B., Marmurowska -Michałowska H., Knap M. Stopień akceptacji przewlekłej obturacyjnej choroby płuc a wsparcie społeczne. Biuletyn Świętokrzyskiej Izby Pielęgniarek i Położnych. 2008;(152)5:610.

14. Iwanicka - Michałowicz M., Grzelewska-Rzymowska I. Czynniki ryzyka przewlekłej obturacyjnej choroby płuc u pacjentów leczonych szpitalnie. Pediatria i Medycyna Rodzinna. 2009:(5)1:27-32. 